\title{
Non-Hellenic Peoples in the Epic Poems of Homer
}

\author{
Nándor LEHRER \\ Institute of History \\ University of Debrecen \\ nandor.lehrer@gmail.com
}

\begin{abstract}
Homer's epic poems represent their contemporary world. These epics give detailed descriptions about the peoples and cultures living in the Mediterranean area. Several ethnic groups appear in the epics, whose home lay far away from the Greek homeland, in the Balkans. The Odyssey may be regarded as the most valuable source of the two epics from a geographical point of view. For instance, this is the first written source of the Kimmers, even if there are only a few verses about them. During his journeys, Ulysses was able to reach several territories, which were less well known in the age of Homer. This is the reason why we have only a less detailed picture of these peoples, and why our knowledge of these cultures, ethnic groups and civilizations is so fragmentary. In my paper I try to figure out how the author described these peoples, what kind of attributes he employed in their description, and how we could interpret this information. Applying all these we could be able to examine the Greek attitude toward foreigners in the $8^{\text {th }}$ century B.C.
\end{abstract}

Keywords: Homer, The Odyssey, Egypt, Acheans

It is always a difficult task to work with Homeric poems. There is still no consensus about the legacy of the Trojan War. It is still a question if the war was an actual event, and if it was, when it occurred. A few years ago scholars thought that Homer's epic poems reflect the world in the $14^{\text {th }}$ century B.C. According to the latest scholarly views (cf. Kolb 2010), the poems could reflect on the reality of the $8^{\text {th }}$ and $7^{\text {th }}$ centuries B.C. ${ }^{1}$ I tend to accept Finley's thesis (1985) of the Homeric poems, regarding these as historical narratives, as the description of the once existed reality, of course, without the world of gods, goddesses and other myths and supernatural factors.

My paper focuses on the foreign peoples appearing in the works of Homer (1998), ${ }^{2}$ as the forms of alterity in antiquity. The most important research question

1 See also the review of Kolb's book written by Stefanie A. H. Kennell in Bryn Mawr Classical Review (Kennell 2011)

2 I am going to use the following abbreviations to distinguish between the two epic poems, for The Iliad: Il., and for The Odyssey: Od. 
is to answer what attributes he used as he was writing about them, and based on it what consequences can be drawn about the attitude of the average man of the age towards foreign peoples. Due to length limitations, it is not possible for me to systematically list each and every people; I only highlight one of them for detailed examination. My choice is Egypt, since this culture had been prospering long before the rise of the Greeks. It is interesting, as Macfarquhar (1966: 108) states in his article, that the Egyptians were fostered by the military ambitions of the Pharaos. That is why early explorers arrived in Egypt and the Mycenaean Greeks got some information about this land. The Homeric poems have preserved this period for us. As Macfarquhar (ibid.) writes, there were only a few things worth mentioning about Egypt in Greek literature between the times of Homer and Hekataios.

If we follow and accept Mary B. Moore's (2000: 13-38) concept, we could say that this age must have been the first "golden age" in the history of Ancient Greece. The Odyssey is set in the iron age of Greece, when sailors necessarily start to engage in long voyages. The foundations of relationships with Italy, for instance, were established at this very time. In the Mycenaean Age long distance trade had been organized with the leadership of palaces, since certain basic and raw materials could only be acquired this way. For example, copper from Cyprus and Sardinia, and tin from the area what is now present-day Afghanistan (Németh 1999: 22).

It must be emphasized that only short references can be found in the works of Homer about quite a number of ethnic groups or countries. However, based on the attributes used we can deduce the natural geographic and economic circumstances of the era. The attributes and dialogues at the same time show us what could have been the Greeks' opinion in that age about each other and about strangers. For example, Homer wrote about people living in the territory around the Black Sea, like the Halizonies, who were used as auxiliary forces by the Trojans. The name of this ethnic group is only mentioned twice, first in the Second Book of The Iliad in the so-called "ship catalogue": ${ }^{3}$

"Odius and Epistrophus were captains over the Halizoni from Distant Alybe, where there are mines of silver.” (Il. II. 856-857)

The second time we can read about them is when King Agamemnon killed their captain, Hodios (Il. V. 37-42). The Paphlagonians, who were also recruited by Troy, also came from this territory.

"The Paphlagonians were commanded by stout-hearted Pylaemanes from Enetae, where the mules run wild in herds." (Il. II. 850-51) 
The Phaecians are also worth mentioning, who helped Ulysses to find his way home. The members of this ancient ethnic group were skilled sailors, that is why they knew the world of that age well. The society of these peoples lay between myth and reality (Raaflaub and Van Wees 2009: 86). We can draw a parallel between the Phaecians and the Phoenicians. Vilmos (2004: 28-33) made a description about trading in the $11^{\text {th }}$ and $10^{\text {th }}$ centuries B.C. He argues that sailing played a great role in the Greek political process no later than the Archaic age. Beside these examples we could list other groups as well. During the enumeration Homer shows us the world as he knew it. We can read the following sentence about Homer in Strabo's Geographika: "the founder of the science of geography" (Strabo 1977: 1, 1, 2). Maury (1918: 97) examined the beginnings of sailing in the age of Homer, and presented Homer himself as a sailor. He claims that we have to regard Homer as the "child of the sea", and that is why the poems are full of preferences about life at sea.

Despite the destructions of the palaces in the $12^{\text {th }}$ century B.C., trade vividly continued, in the course of which the Greeks got into contact with other cultures. This is also supported by the imported objects, for instance, Egyptian scarabs and glass shards, iron knives from Syria, seals from Cyprus, and even amber from the Baltic region were found in the area known as Hellas (Osborne 1996: 20). It must also be emphasized that in the second transitional period of the history of the Hittite Empire (14 ${ }^{\text {th }}$ century B.C.) new cultures emerged in Anatolia. For instance, the Achaeans or the Lycians also appeared in this time. Most of the records that remained of the Hittite Empire are written. Based on the interpretation of the Hittite documents and references found on Egyptian scrolls any kind of connection between the Hittite Empire and the Achaeans was possible. The literature of the domain assumes that this must have been a relationship of diplomatic and military nature (Raaflaub 2006: 451). The excavated archaeological findings prove that the Greeks and Egypt had a connection even in the earliest times. The first hieroglyphic record with the names of several cities of the Aegean Sea were found in the funerary temple of Amenhotep III (Cline and Stannish 2011: 6-16). All of the written and non-written records confirm that "the realm of the Pharaohs" was not just present in the life of the early Greeks, but it also played a decisive part. According to the epic poems of Homer, I try to focus on the Greek image of "the gift of the Nile".

In The Iliad, Achilles brings up Egypt as an example, more exactly, Thebes, whose name was known by the Greeks from the age of Homer. The following can be read:

He may offer me ten or even twenty times what he has now done, nay- not though it be all that he has in the world, both now or ever shall have; he may promise me the wealth of Orchomenus or of Egyptian Thebes, which 
is the richest city in the whole world, for it has a hundred gates through each of which two hundred men may drive at once with their chariots and horses; he may offer me gifts as the sands of the sea or the dust of the plain in multitude, but even so he shall not move me till I have been revenged in full for the bitter wrong he has made me. (Il. IX. 379-87)

Based on the citation above, we learn that as far as Achilles-thus, Homerknows, Egypt and Thebes has the most treasures in the region. Earliest layers of the settlement date back to before 3200 B.C. In the age of the Old Empire ${ }^{4}$ the "capital of the fourth Upper Egyptian nomos was a third rate small town in the country" (Shaw 2000: 149). It will be the capital of the country later, in the period of the Middle Empire, under the eleventh dynasty (Mentuhotep and his descendants), until the end of the dynasty (Kákosy 1993: 107). The poet emphasizes the wealth of the capital with the number of the city gates, of which there are a hundred, based on the description, and two hundred horsemen can pass under each of them at the same time. The number is obviously overdrawn but it shows well that the Achaeans of the age regarded Egypt as the land of wealth. This is not even surprising if we accept János Sarkady's (1970: 17) opinion according to which the life of early Hellas seems primitive if compared to the past and achievements of the ancient Eastern peoples. It must also be added that Egypt was in its golden age in the time of the New Empire. ${ }^{5}$ An unprecedented number of construction projects were initiated, and luxury was characteristic of their culture and way of life (Shaw 2000: 288). The court of Amenhotep became a diplomatic centre, the relationship system established with the neighbouring states made Egypt more open towards the assimilation of foreign cultures (ibid.). The story of Menelaus can be an excellent example of this. We know the events from two descriptions: one of them is The Odyssey, the other work is Histories by Herodotus (hereinafter: Hdt.).

Before we proceed in the story we have to stop for a while to speak a little bit about Herodotus' work. We should take a look at his visit to Egypt. At that time the Greeks had known that country for approximately two hundred years (Brown 1965: 60). One of the main problems about Herodotus ${ }^{6}$ is that he did not speak the Egyptian language, and he did not have access to the Egyptian records. Everything he wrote and he knew about the Greeks can be traced back to records written in any ancient dialects of the Greek language. As I have observed in my readings of Egypt by Herodotus, the Egyptian people did exactly the opposite

4 There is a difference in the dating of the age. According to the generally accepted opinion the period between the third dynasty and the sixth dynasty is the age of the Old Empire.

5 The literature considers the period between 1352 B.C. and 1069 B.C. to be the New Empire.

6 This topic has a wide range literature with several studies and commentaries. For example, the early but still very useful commentary: How \& Wells 1912. 
of the Greeks. It can be easily perceived reading the records about the habits of Egyptians. $^{7}$

We know the story of Menelaus from Book Four of The Odyssey. Telemachus arrives at the palace of the Spartan king to inquire about his father. After the sack of Troy and recovery of Helen, the Spartan contingent sets off towards home. On the way, however, they get into a storm, which splits the convoy into two. Menelaus finally arrives in the land of Egypt with five ships altogether.

[...] but at all events I have travelled much and have undergone much hardship, for it was nearly eight years before I could get home with my fleet. I went to Cyprus, Phoenicia and the Egyptians; I went also to the Ethiopians, the Sidonians, and the Erembians, and to Libya, where the lambs have horns as soon as they are born, and the sheep bear lambs three times a year. Every one in that country, whether master or man, has plenty of cheese, meat, and good milk, for the ewes yield all the year round. But while I was travelling and getting great riches among these people ${ }_{[\ldots]}(\mathrm{Od}$. IV. 81-90)

We learn about his voyage from this passage. He met several peoples, gathered a lot of treasure and he finally managed to take them home. As a way of boasting, he describes them in detail to Telemachus. The magnificence of Menelaus' palace is mostly due to the treasures newly acquired from Egypt. In the course of the detailed description it turns out that they spent time in Egypt, and he brought the most expensive pieces of treasure from there:

Phylo fetched her the silver work-box which Alkandra wife of Polybos had given her. Polybos lived in Egyptian Thebes, which is the richest city in the whole world; he gave Menelaus two baths, both of pure silver, two tripods, and ten talents of gold; besides all this, his wife gave Helen some beautiful presents, to wit, a golden distaff, and a silver work-box that ran on wheels, with a gold band round the top of it. (Od. IV. 125-32)

His stay in Egypt can also be considered a kind of deliberate treasure hoarding voyage:

As for the other five ships, they were taken by winds and seas to Egypt, where Menelaus gathered much gold and substance among people of an alien speech. (Od. III. 300-301)

Beside the multitude of valuable objects made of precious metals the persons of Alkandra and Polybos appear by name. Based on the description

$7 \quad$ For further reading: Hdt. Book II. 
they live in Thebes, but based on their names they seem much more of Greek origin than Egyptians.

Based on the narrative of Herodotus, Menelaus ${ }^{8}$ and his companions did not leave the land of the Pharaohs peacefully.

Since his departure was hindered by unfavorable weather, and since it lasted for a long time, he decided to commit a despicable act: he had a local man's two children kidnapped and sacrificed. (Hdt. II. 119)

After this act was found out, the angry natives wanted to kill them, so they fled to Libya. Herodotus considers this version of the story true, and makes the observation regarding Homer that although he knew well that Helen was in Egypt, this did not fit into the epic, so he altered the story a bit. Besides this, another difference can be found between the two stories that can be conspicuous. Homer states that Menelaus and his companions were in the city of Thebes; Herodotus writes that they were in Memphis. ${ }^{9}$

Despite these contradictions, it can be discerned in both works that at an early stage the Egyptians were friendly towards all foreigners, but almost after the first sign of misbehaviour they tried to drive away all the foreigners from their land. Such a story can be read in Homer as well. In the story of Castor Hylacides, following his return to Ithaca, Ulysses introduces himself to Eumaeus as a rich, but unadventurous Cretan man.

On the fifth day we reached the river Aegyptus; there I stationed my ships in the river, bidding my men stay with them and keep guard over them while I sent out scouts to reconnoiter from every point of vantage. But the men disobeyed my orders, took to their own devices, and ravaged the land of the Egyptians, killing the men, and taking their wives and children captive. The alarm was soon carried to the city, and when they heard the war cry, the people came out at daybreak. (Od. XIV. 257-66)

From the rest of the text, it turns out that a clash ensued, in the course of which many of his companions were killed. Castor Hylacides begs for mercy, turning to the Egyptian king, and he is forgiven. Based on the narrative, he lived for seven years among them following these events.

[...] Then I went straight up to the king's chariot, clasped his knees and kissed them, whereon he spared my life, bade me get into his chariot, and took me weeping to his own home. Many made at me with their ashen spears

8 See also: Neville 1977.

9 During most of the New Empire era Memphis was the administrative centre, de facto the capital. 
and tried to kill me in their fury, but the king protected me, for he feared the wrath of Jove the protector of strangers, who punishes those who do evil. I stayed there for seven years and got together much money among the Egyptians, for they all gave me something. (Od. XIV. 278-86)

Summarizing the above mentioned data, we can draw the following conclusions from the passages cited above. In the Homerian oeuvre livestock breeding and agriculture had a priority role. This was confirmed in Finley's work in which he says that Ulysses regarded other peoples as barbarians since they had not acquired the science of agriculture. Such a story can be read in the ninth book of The Odyssey. Ulysses tells his story about the Cyclops at Alkinoos' palace. The problem is that farming always had a priority in agriculture because the Greek landscape was not perfectly suitable for farming unlike breeding animals (Finley 1985: 81). In Egypt the discovered areas were full of beautiful pastures and wheat. The cause of this is that the regular flooding of the Nile spread a fertile layer of mud over the river valley. This is how a vivid agriculture could be established with the help of irrigation. In contrast with Mesopotamia, the goal was not to regulate the river and to keep away the flood, but they tried to keep the overflowing water on the fields in order to settle the extraordinarily fertile mud brought by the flood as completely as possible.

I suggest that Egypt has always been a special case. ${ }^{10}$ Reading the situations above, we get a picture of an open-minded, friendly civilization existing in the age of the New Empire, which, on the other hand, is capable of engaging in a fight any time to protect their interests, their homeland. The wealth which was presented by Homer was exceptional in that age. This can be noticed mostly from The Iliad, from the description of Thebes; the references, enriched with unrealistic exaggerations allow for the conclusion that the Greeks of the age regarded this area with awe, even long after Homer's age.

I wish to close my paper with the words of Herodotus:

I will speak of Egypt more, for there are more that is wonderful in Egypt than in any other country, and it can boast of such accomplishments almost no words can describe. (Hdt. II. 35) 


\section{Sources}

Hérodotosz 2007. A görög-perzsa háború. [Herodotus: Histories.] Translated by Gyula Muraközi. Budapest: Osiris Kiadó.

Homer. 1998. The Iliad. Translated by Samuel Butler. Online text, Orange Street Classics.

---. 1998. The Odyssey. Translated by Samuel Butler. Online text, Orange Street Classics.

Sztrabón. 1977. Geógraphika. [Strabo: Geography.] Translated by József Földy. Budapest: Gondolat.

\section{References}

Allen, T.W. 1910. The Homeric Catalogue. The Journal of Hellenic Studies 30: 292-322.

Brown, Truesdell S. 1965. Herodotus Speculates about Egypt. The American Journal of Philology 86 (1): 60-76.

Cline, Eric H. \& Steven M. Stannish. 2011. Sailing the Great Sea? Amenhotep III's Aegean List from Kom El-Hetan, Once More. Journal of Ancient Egyptian Interconnections 3 (2): 6-16.

Cline, Eric. 1987. Amenhotep III and the Aegean: A Reassessment of EgyptoAegean Relations in the $14^{\text {th }}$ Century B.C. Orientalia 56 (1): 1-36.

Finley, Moses I. 1985. Odüsszeusz világa. [The World of Odysseus.] Budapest: Európa Könyvkiadó.

How, W. W. and J. Wells. 1912. A Commentary on Herodotus. Oxford University Press.

Kákosy, László. 1993. Ré fiai. [The Sons of Re.] BUK: Százszorszép Kiadó.

Kennell, Stefanie A. H. (2011.) Frank Kolb's book review in Mawr Classical Review. http://bmcr.brynmawr.edu/2011/2011-07-12.html

Kolb, Frank. 2010. Tatort "Troia": Geschichte, Mythen, Politik. Paderborn: Ferdinand Schöningh.

Macfarquhar, C. F. 1966. Early Greek Travellers in Egypt. Greece \& Rome, Second Series, 13 (1): 108-116.

Maury, C. A. 1918. Maritime Aspects of Homeric Greece. The Classical Journal 14 (2): 97-102.

Moore, Mary B. 2000. Ships on a "Wine-Dark Sea" in the Age of Homer. Metropolitan Museum Journal 35: 13-38.

Németh, György. 1999. A polisok világa. [The World of Polises.] Budapest: Korona Kiadó. 
Neville, James W. 1977. Herodotus on the Trojan War. Greece \& Rome, Second Series, 24 (1): 3-12.

Osborne, Robin. 1996. Greece in the Making 1200-479 B.C. London \& New York: Routledge.

Raaflaub, Kurt A. 2006. Historical Approaches to Homer. In: Deger-Jalkotzy, Sigrid, Irene S. Lemos (eds.), Ancient Greece. From the Mycenaean Places to the Age of Homer, 449-462. Edinburgh: Edinburgh University Press.

Raaflaub, Kurt A. and Hans van Wees (eds.). 2009. A Companion to Archaic Greece. Blackwell Publishing.

Sarkady, János. 1970. Gazdasági élet az ókori Görögországban. [Economic Life in Ancient Greece.] Budapest: Gondolat.

Shaw, Ian (ed.) 2000. Az ókori Egyiptom története. [The History of Ancient Egypt.] Gold Book.

Vilmos, László. 2004. A hajózás jelentősége az archaikus Görögországban. [The Significance of Sailing in Archaic Greece.] Ókor. Folyóirat az antik kultúrákról. [Antiquity. A Journal about Ancient Cultures.] 3: 28-33. 